\title{
Thematic Content Analysis for Pre-School Science Education Research Areas in Turkey
}

\author{
Hatice GÜLER *1 (D) Erol TAŞ ${ }^{2}$ (D) \\ ${ }^{1}$ Giresun University, Eynesil Vocational High School, Giresun, Turkey, hatice_kpc@hotmail.com \\ ${ }^{2}$ Ordu University, Education Faculty, Ordu, Turkey, eroltas@odu.edu.tr \\ *Corresponding Author: hatice_kpc@hotmail.com
}

Article Info \begin{abstract}
The purpose of this research is to examine the various variables in terms of master dissertations, doctoral dissertations, and articles made in the field of science education in pre-school between the years 2014 and 2019 in Turkey. The present study is a qualitative research. In this study, thematic content analysis was used. After the articles deriving from the dissertations were extracted, a total of 129 publications including 14 doctoral dissertations, 38 master dissertations and 77 articles were reached. At the end of the research, it is seen that most of the postgraduate theses were published in Gazi University and the most articles were published in The Journal of International Social Research. When the distribution of the studies according to the aims of the studies is examined, it is seen that determination studies produced the highest effect while the quantitative studies were conducted at most, considering the research methods. While participant groups mostly involved the students, the scale and interviews were preferred as data collection tools. In accordance with these results, suggestions were made to the researchers who would work on this subject.
\end{abstract}

Received: 31 January 2020 Accepted: 22 Mart 2020

Keywords: Preschool, science education, thematic content analysis

DOI: $10.18009 /$ jcer.683041

Publication Language: English

open access (a) CrossMark (c)

To cite this article: Güler, H. \& Taş, E. (2020). Thematic content analysis for pre-school science education research areas in turkey. Journal of Computer and Education Research, 8 (15), 323-343. DOI: $10.18009 /$ jcer.683041

\section{Introduction}

The development and self-renewal of knowledge day by day triggers societies to raise qualified individuals who keep up with this development. Particular emphasis is placed on science education which enables individuals to produce solutions to the problems they encounter in daily life and apply scientific process skills in addition to the knowledge they have acquired during the education process. Researchers working in this field suggest that science education should be included in all stages of education from pre-school (Çakmak, 2006).

Science is an indispensable part of our daily life. It is very important because planting, to observe the germination of seeds, to think about why the boat does not sink in water, to observe that some animals fly while others live in water, to know that the day and 
night follows a never-changing cycle, to learn the characteristics of water and rainbow are the information we will gain with science education. All of these are concrete experiences that children will acquire in preschool by using their senses (Şahin, 2000). In addition, these activities support children to learn scientific processes and gain the ability to solve universal problems. In this context, science and nature activities have an important place in preschool education programs.

The pre-school is a period in which children are curious, investigative, willing, and open to learning. For this reason, they try to learn everything they encounter in everyday life and cannot understand through asking questions. The concepts of science are the ones they encounter and wonder most in daily life. Therefore, the first experiences of science begin in this period and form the basis for their progressing life (Cevher-Kalburan, 2009). The science education in the preschool period gives children an opportunity to understand what they wonder at the surroundings and to apply their scientific process skills by making use of children's desire of discovery. It also helps them to develop positive thinking about science (Takaoğlu \& Demir, 2018). For this reason, planned activities in preschool institutions should be shaped according to their environment and preschool theories and should be supported in order to eliminate children's questions and curiosities. Moreover, the learning environment should be well organized, be added to daily life and other activities, and provide appropriate science experiences for all children.

Researchers play an important role in improving the quality of science education for young children as well as schools, families, and teachers. For this reason, all the researches about science education in early childhood is indeed one of the important factors affecting the quality and effectiveness of science education programs positively and directly (ErtürkKara \& Aydın-Şengül, 2016).

In our country, studies related to pre-school education have accelerated after 2000s (Taşkın \& Şahin, 2008). Therefore, it is thought that preschool science education studies are still in a development process in our country and the studies to be conducted in this field will make significant contributions to the literature (Özen-Uyar \& Ormanc1, 2016). However, it is questionable how much of these studies are related to science education. It is expected that determining the current situation in the area of preschool science education which the detected that there are deficiencies in the work area in Turkey and carrying out the new studies planned in the required areas will contribute to the field (Özen-Uyar \& Ormanc1, 
2016). In this case, investigations and meta-synthesis studies provide guidance for researchers. When national databases are examined, it is seen that many studies have been conducted in many areas in early childhood (Kaytez \& Durualp, 2014; Can-Yaşar \& Aral, 2011). Similar studies were conducted in the field of science education in pre-school (Gülay Ogelman \& Güngör, 2015; Ertürk-Kara \& Aydın-Şengül, 2016; Özen-Uyar \& Ormanc1, 2016; Avar \& Ilıcan, 2018; Güneş, 2018). However, the study covering the last six years is not included in the literature. In addition, the studies conducted in recent years have dealt with either theses or articles only. There is no study in the literature examining theses and articles related to pre-school science education together. The purpose of this research is to examine the various variables in terms of master dissertations, doctoral dissertations, and articles made in the field of science education in pre-school between the years 2014 and 2019 in Turkey. For this purpose, the following research questions were tried to be answered:

1. What is the distribution of external appearance characteristics of the research? (type of publication, year of publication, place of publication, area of master study of the author)

2. What are the aims of the research?

3. What methods have the research been done?

4. What is the distribution of the participants of the research?

5. What is the distribution of research data collection tools?

6. What is the distribution of methods and techniques used in researches?

What is the distribution of research topics?

\section{Methodology}

This study is a qualitative research which examined the studies carried out in the field of pre-school science education in Turkey between the years 2014 and 2019. Thematic content analysis (meta-synthesis), one of the content analysis types, was used in the current research. Thematic content analysis involves creating, synthesizing, and interpreting the themes or parameters of researches conducted in the same field and in the same subject (Au, 2007; Çalık \& Sözbilir, 2014).

\section{Data Collection}

This study consists of master's theses, doctoral theses, and articles in the field of Science Education in preschool period. In the process of data collection, Master's and 
doctoral theses were obtained from the National thesis center database of the Board of Higher Education and the articles were obtained from the journals published in Turkey and scanned in the database of Social Sciences Citation Index (SSCI), Ulakbim National Social Sciences Database, and Google Scholar. During the process of scanning, the following keywords were used: "preschool education, preschool science education, science teaching preschool, preschool science activities, preschool science and Nature, Science and nature activities, science and Nature Education, Early Childhood Education, Environmental Education, Science Education in pre-school". The abstracts of 4 doctoral theses and 5 Master theses were included in the study as no access to the theses were permitted. In addition, if there was an article produced by the same author of the postgraduate thesis, the postgraduate thesis was preferred. In the light of these criteria, a total of 129 publications were reached including 14 doctoral theses, 38 master theses, and 77 articles. In spite of all the scans carried out, it has been thought that not all publications could be reached. This situation and the fact that the study covers the years 2014-2019 are the limitations of the research.

\section{Data Analysis}

The articles and dissertations scanned from the field were recorded in categories. Then, parameters were determined in the subjects connected with the research questions and forming the skeleton of a research. Parameters were identified in th form of appearance characteristics (publication type, publication year, place of publication, the author's master field of study), content properties (research method, data collection tools, participant groups, research objectives and research method used in-technical). In line with these parameters, all articles and theses were examined in detail and tabulated. Later, content analysis was done and the codes were developed into sub-themes and themes. Frequencies and percentages were used to make the data more comprehensible.

A coding framework similar to the one used by Ormancı, Çepni, Deveci and Aydın (2015) in the analysis of the data was established. Detailed information on the generated Coding Framework is presented in Table 1. 
Table 1. An example of the parameters in which the studies are examined

\begin{tabular}{lll}
\hline Theme & Sub Theme & Description \\
\hline Exterior Features & $\begin{array}{l}\text { Place of publication } \\
\text { Year } \\
\text { Type } \\
\text { Author's field of postgraduate } \\
\text { studies }\end{array}$ & $\begin{array}{l}\text { Published in the journal or uni. } \\
\text { Publication year } \\
\text { Publication type } \\
\text { The author's recent training in what } \\
\text { field }\end{array}$ \\
\hline Content Features & $\begin{array}{l}\text { Purpose of research } \\
\text { Method }\end{array}$ & $\begin{array}{l}\text { Quantitative, qualitative, hybrid } \\
\text { Participating groups } \\
\text { Data collection tool } \\
\text { Science subject } \\
\text { Method-technique }\end{array}$ \\
& $\begin{array}{l}\text { Student, teacher, parent, etc. } \\
\text { The subject of the study was made } \\
\text { Method-technique used in the study }\end{array}$ \\
\hline
\end{tabular}

\section{Finding and Discussion}

In this section, the master theses, doctoral theses, and articles were examined within the scope of the research are presented in tables with the help of codes and themes.

\section{Findings Related to External Features of Research}

Table 2. Distribution of examined master's and doctorate theses by university.

\begin{tabular}{|c|c|c|c|c|c|}
\hline Theme & Code & $\begin{array}{l}\text { Master } \\
\text { Thesis }\end{array}$ & $\begin{array}{c}\text { Doctoral } \\
\text { Thesis }\end{array}$ & tf & $\%$ \\
\hline \multirow{32}{*}{$\begin{array}{l}\text { University } \\
\text { Name }\end{array}$} & Gazi Uuniversity & 2 & 4 & 6 & 11,54 \\
\hline & Çanakkale Onsekiz Mart Uni. & 4 & 0 & 4 & 7,70 \\
\hline & Bahçeşehir Üniversitesi & 3 & 0 & 3 & 5,77 \\
\hline & Recep Tayyip Erdoğan Uni. & 3 & 0 & 3 & 5,77 \\
\hline & Kastamonu University & 3 & 0 & 3 & 5,77 \\
\hline & Hacettepe University & 0 & 2 & 2 & 3,85 \\
\hline & Necmettin Erbakan Uni. & 2 & 0 & 2 & 3,85 \\
\hline & Bartın University & 2 & 0 & 2 & 3,85 \\
\hline & Pamukkale University & 1 & 1 & 2 & 3,85 \\
\hline & Abant İzzet Baysal Uni. & 1 & 1 & 2 & 3,85 \\
\hline & Çukurova University & 1 & 1 & 2 & 3,85 \\
\hline & Marmara University & 0 & 1 & 1 & 1,92 \\
\hline & Ankara University & 0 & 1 & 1 & 1,92 \\
\hline & Karadeniz Technical Uni & 0 & 1 & 1 & 1,92 \\
\hline & Boğaziçi University & 1 & 0 & 1 & 1,92 \\
\hline & Gaziosmanpaşa University & 1 & 0 & 1 & 1,92 \\
\hline & Mustafa Kemal University & 1 & 0 & 1 & 1,92 \\
\hline & Yeditepe University & 1 & 0 & 1 & 1,92 \\
\hline & Uludağ University & 1 & 0 & 1 & 1,92 \\
\hline & Ahi Evran University & 1 & 0 & 1 & 1,92 \\
\hline & Uşak University & 1 & 0 & 1 & 1,92 \\
\hline & Kafkas University & 1 & 0 & 1 & 1,92 \\
\hline & Aydın University & 1 & 0 & 1 & 1,92 \\
\hline & Trakya University & 1 & 0 & 1 & 1,92 \\
\hline & Aksaray University & 1 & 0 & 1 & 1,92 \\
\hline & Dumlupınar University & 1 & 0 & 1 & 1,92 \\
\hline & Akdeniz University & 1 & 0 & 1 & 1,92 \\
\hline & Yıldız Technical University & 1 & 0 & 1 & 1,92 \\
\hline & Afyon Kocatepe University & 1 & 0 & 1 & 1,92 \\
\hline & Ortadoğu Technical University & 0 & 1 & 1 & 1,92 \\
\hline & Erciyes University & 0 & 1 & 1 & 1,92 \\
\hline & Dokuz Eylul University & 1 & 0 & 1 & 1,92 \\
\hline Total & & 38 & 14 & 52 & 100 \\
\hline
\end{tabular}


Table 2 shows the percentage and frequency distribution of postgraduate theses in science education in preschool period according to universities. When Table 2 was examined, the maximum number of postgraduate thesis studies were conducted at Gazi University $(\mathrm{f}=6)$ with a ratio of $11,54 \%$. It was followed by Çanakkale Onsekizmart University $(\mathrm{f}=4)$ with a rate of 7,70\%. Similarly, Ertürk-Kara and Aydın-Şengül (2016) found that more postgraduate theses were made at Gazi University in their study. When we look at the table, master's theses are more than doctoral theses. This result is natural, especially due to the scarcity of doctoral programs in Anatolian universities. What is striking here is the lack of publications in established universities such as Hacettepe University, Marmara University, and Boğaziçi University.

Table 3. Distribution of reviewed articles by published journals

\begin{tabular}{|c|c|c|c|}
\hline Theme & Code & f & $\%$ \\
\hline \multirow{13}{*}{ Journal Name } & Education and Science & 3 & 3,90 \\
\hline & Educational Sciences in Theory And Practice & 1 & 1,30 \\
\hline & International Journal of Education in & 1 & 1,30 \\
\hline & Mathematics, Science and Technology (IJEMST) & & \\
\hline & Creative Drama Journal & 1 & 1,30 \\
\hline & Elementary Education Online & 4 & 5,20 \\
\hline & DPÜ Journal of Educational Sciences & 1 & 1,30 \\
\hline & Journal of Human Science & 2 & 2,60 \\
\hline & Atatürk University Kazım Karabekir Journal of the Faculty of Education & 1 & 1,30 \\
\hline & International Journal of Social Sciences And Education Research & 1 & 1,30 \\
\hline & The Journal of International Social Research & 4 & 5,20 \\
\hline & The Black Sea Journal of Social Sciences & 2 & 2,60 \\
\hline & Journal of Research in Education and Teaching & 1 & 1,30 \\
\hline \multirow{27}{*}{ Journal Name } & Mediterranean Journal of Educational Research & 1 & 1,30 \\
\hline & Hitit University Journal of Institute of Social Sciences & 1 & 1,30 \\
\hline & Inönü University Journal of The Faculty of Education & 2 & 2,60 \\
\hline & Mersin University Journal of The Faculty of Education & 2 & 2,60 \\
\hline & Mehmet Akif Ersoy University Journal of The Faculty of Education & 1 & 1,30 \\
\hline & Cumhuriyet University Journal of The Faculty of Education & 1 & 1,30 \\
\hline & Journal of Theoretical Education & 1 & 1,30 \\
\hline & Journal of Education for Life & 1 & 1,30 \\
\hline & Caucasian Journal of Science & 1 & 1,30 \\
\hline & Electronic Turkish Studies & 1 & 1,30 \\
\hline & Eurasian Journal of Researches İn Social And Economics & 1 & 1,30 \\
\hline & Hacettepe University Journal of The Faculty of Education & 1 & 1,30 \\
\hline & Bayburt Journal of The Faculty of Education & 2 & 2,60 \\
\hline & Bilecik Şeyh Edebali University Journal of Social Sciences & 1 & 1,30 \\
\hline & Journal of Social Sciences & 1 & 1,30 \\
\hline & Anatolian Journal of Educational Leadership And Teaching & 1 & 1,30 \\
\hline & Atatürk University Journal of the Institute of Social Sciences & 1 & 1,30 \\
\hline & International Journal of Social Sciences Education & 1 & 1,30 \\
\hline & International Journal of Educational Sciences & 2 & 2,60 \\
\hline & The Journal of Academic Social Science Studies & 1 & 1,30 \\
\hline & Route Educational And Social Science Journal & 1 & 1,30 \\
\hline & The Journal of Academic Perspective & 1 & 1,30 \\
\hline & Abant İzzet Baysal University Journal of The Faculty of Education & 1 & 1,30 \\
\hline & Universal Journal of Educational Research & 1 & 1,30 \\
\hline & Pegem Journal of Education and Training & 1 & 1,30 \\
\hline & International Online Journal of Educational Sciences & 1 & 1,30 \\
\hline & Asıan Academıc Research Journal of Multıdısciplınary & 1 & 1,30 \\
\hline
\end{tabular}




\begin{tabular}{|c|c|c|c|}
\hline & International Journal of Progressive Education & 1 & 1,30 \\
\hline & International Journal of Early Childhood Education Studies & 1 & 1,30 \\
\hline & Kastamonu Education Journal & 2 & 2,60 \\
\hline & Journal of Academic Social Research & 2 & 2,60 \\
\hline & Çukurova University Journal of The Faculty of Education & 1 & 1,30 \\
\hline & Journal of Early Childhood Studies & 1 & 1,30 \\
\hline & Mustafa Kemal University Journal of Institute of Social Science & 1 & 1,30 \\
\hline & International Journal of Turkish Educational Sciences & 1 & 1,30 \\
\hline & International Journal of Family, Child and Education & 1 & 1,30 \\
\hline & Erzincan University Journal of The Faculty of Education & 2 & 2,60 \\
\hline & International Journal of Scientific Research & 1 & 1,30 \\
\hline & The Journal of Educational Reflections & 1 & 1,30 \\
\hline & Journal of Awareness & 1 & 1,30 \\
\hline & Journal of Research in Informal & 1 & 1,30 \\
\hline & Turkish Journal of Primary Education & 1 & 1,30 \\
\hline & Gazi Journal of Educational Sciences & 1 & 1,30 \\
\hline & Journal oj Humanities and Social Sciences Research & 1 & 1,30 \\
\hline & E-Kafkas Journal of Educational Research & 1 & 1,30 \\
\hline & Karamanoğlu Mehmetbey International Journal of Educational Research & 1 & 1,30 \\
\hline & Celal Bayar University Journal of Social Sciences & 1 & 1,30 \\
\hline & Pegem Citation Index & 1 & 1,30 \\
\hline Total & & 77 & 100 \\
\hline
\end{tabular}

Table 3 indicates that at most 5,20\% of the articles published in the field of pre-school science education between 2014-2019 were published in The Journal of International Social Research $(f=4)$ and Elementary Education Online $(f=4) .5,20 \%(f=4)$ of SSCI indexed journals were published. Özen-Uyar and Ormanc1 (2016) found that $16,70 \%$ of the articles published in the field of science education in pre-school period between 2010 and 2016 were published in SSCI indexed journals in a similar study.

Table 4. Distribution of studies reviewed by publication year

\begin{tabular}{|c|c|c|c|c|c|c|c|c|c|}
\hline \multirow[t]{2}{*}{ Theme } & \multirow[t]{2}{*}{ Code } & \multicolumn{2}{|c|}{$\begin{array}{l}\text { Master } \\
\text { Thesis }\end{array}$} & \multicolumn{2}{|c|}{$\begin{array}{c}\text { Doctoral } \\
\text { Thesis }\end{array}$} & \multicolumn{2}{|c|}{ Article } & \multicolumn{2}{|c|}{ Total } \\
\hline & & $\mathbf{f}$ & $\%$ & $\mathbf{f}$ & $\%$ & f & $\%$ & $f$ & $\%$ \\
\hline \multirow{6}{*}{ Years } & 2014 & 3 & 7,90 & 1 & 7,14 & 5 & 6,50 & 9 & 6,98 \\
\hline & 2015 & 4 & 10,52 & 6 & 42,86 & 24 & 31,17 & 34 & 26,36 \\
\hline & 2016 & 8 & 21,10 & 2 & 14,29 & 12 & 15,59 & 22 & 17,06 \\
\hline & 2017 & 2 & 5,26 & 2 & 14,29 & 9 & 11,69 & 13 & 10,08 \\
\hline & 2018 & 7 & 18,42 & 0 & 0 & 12 & 15,59 & 19 & 14 \\
\hline & 2019 & 14 & 36,84 & 3 & 21,43 & 15 & 19,48 & 32 & 24,81 \\
\hline Total & & 38 & 100 & 14 & 100 & 77 & 100 & 129 & 100 \\
\hline
\end{tabular}

Table 4 shows the distribution of publications by years. When the table is examined, it is seen that the most publications were made in $2015(26,36 \%, \mathrm{f}=34) .11 .8 \%$ of these publications consist of master's thesis $(f=4), 17.7 \%$ of doctoral thesis $(f=6)$, and $70.5 \%$ of articles $(f=24)$. When the master theses were examined, it was concluded that the highest number of publications was made in $2019(36,84 \%, \mathrm{f}=14)$. When the doctoral dissertations are examined, it is seen that the most publications were made in $2015(42,86 \%, \mathrm{f}=6)$. In addition, no doctoral dissertation was published in 2018. Finally, when the articles were 
examined, the highest number of articles was published in 2015 31,17\%, (f=24). Özen Uyar and Ormanc1 (2016) examined the articles published between 2010 and 2016 and found that 22 of the 72 articles (30.50\%) were published in 2015. In another study, Ertürk Kara and Aydın Şengül (2016) examined the articles published on the same subject between 2000 and 2015 and found that the most articles were published in 2012 with a rate of $20.0 \%(f=6)$. Many studies conducted in this field show that the number of publications has increased since 2000 (Gülay-Ogelman \& Güngör, 2015; Ertürk-Kara \& Aydın-Şengül, 2016; Uyar \& Ormanc1, 2016; Avar \& Ilıcan, 2018; Güneş, 2018). It is noteworthy that the number of studies in science education in pre-school period has increased after 2014.

Table 5. Distribution of studies examined by type of publication

\begin{tabular}{cccc}
\hline Theme & Code & $\mathbf{f}$ & $\mathbf{\%}$ \\
\hline \multirow{3}{*}{ Publication Type } & Master Thesis & 38 & 29,46 \\
\cline { 2 - 4 } & Doctoral Thesis & 14 & 10,86 \\
\cline { 2 - 4 } & Article & 77 & 59,69 \\
\hline Total & & $\mathbf{1 2 9}$ & $\mathbf{1 0 0}$ \\
\hline
\end{tabular}

Accordig to Table 5, the most articles were published in the field of Science.

Education in preschool period between 2014-2019 compared to 59,69\% ( $\mathrm{f}=77$ ). 29,46\% ( $\mathrm{f}=38$ ) was followed by master's thesis. Finally, doctoral dissertations were the least published studies with a ratio of $10,86 \%(\mathrm{f}=14)$.

Table 6. Distribution of the authors of the studies studied in the areas of postgraduate education

\begin{tabular}{|c|c|c|c|c|c|c|c|c|c|}
\hline \multirow[t]{2}{*}{ Theme } & \multirow[t]{2}{*}{ Code } & \multicolumn{2}{|c|}{$\begin{array}{l}\text { Master } \\
\text { Thesis }\end{array}$} & \multicolumn{2}{|c|}{$\begin{array}{c}\text { Doctoral } \\
\text { Thesis }\end{array}$} & \multicolumn{2}{|c|}{ Article } & \multicolumn{2}{|c|}{ Total } \\
\hline & & $\mathrm{f}$ & $\%$ & f & $\%$ & f & $\%$ & $\mathbf{f}$ & $\%$ \\
\hline \multirow{12}{*}{ 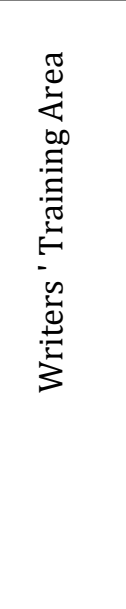 } & Preschool Education & 22 & 57,90 & 10 & 71,43 & 40 & 51,95 & 72 & 55,81 \\
\hline & Science Education & 7 & 18,42 & 3 & 21,43 & 13 & 16,88 & 23 & 17,83 \\
\hline & Child Development & 0 & 0 & 1 & 7,14 & 9 & 11,69 & 10 & 7,75 \\
\hline & Classroom Education & 2 & 5,26 & 0 & 0 & 3 & 3,90 & 5 & 3,88 \\
\hline & Chemistry Education & 0 & 0 & 0 & 0 & 6 & 7,80 & 6 & 4,65 \\
\hline & Physics Education & 0 & 0 & 0 & 0 & 2 & 2,60 & 2 & 1,55 \\
\hline & Biology Education & 0 & 0 & 0 & 0 & 1 & 1,30 & 1 & 0,78 \\
\hline & Departmant of Chemistry & 0 & 0 & 0 & 0 & 1 & 1,30 & 1 & 0,78 \\
\hline & Special Education & 0 & 0 & 0 & 0 & 1 & 1,30 & 1 & 0,78 \\
\hline & $\begin{array}{c}\text { Department of } \\
\text { Elementary Education }\end{array}$ & 3 & 7,90 & 0 & 0 & 0 & 0 & 3 & 2,33 \\
\hline & $\begin{array}{l}\text { Education Management } \\
\text { and Supervision }\end{array}$ & 3 & 7,90 & 0 & 0 & 1 & 1,30 & 4 & 3,10 \\
\hline & Lifelong Learning & 1 & 2,63 & 0 & 0 & 0 & 0 & 1 & 0,78 \\
\hline Total & & 38 & 100 & 14 & 100 & 77 & 100 & 129 & 100 \\
\hline
\end{tabular}

Table 6 shows the distribution of the most recent postgraduate education of the authors who research on science education in preschool. Here, the field of education of the first author of the studies with multiple authors was examined. It is also seen that approximately half of the researchers in the total of all types of publications are researchers 
in the field of preschool education $(55,81 \%, \mathrm{f}=72)$. In the second place, researchers in the field of science education $(17,83 \%, \mathrm{f}=23)$ are seen. It is noteworthy that the fields of education of the authors vary especially in the type of articles. It is seen that $57,90 \%(f=22)$ of the master's theses made in this field are in the field of pre-school education and $18,42 \%(f=$ 7) were in the field of science education. As in the other two types of dissertations, the highest number of studies was made in the field of preschool education $(71,43 \%, f=10)$. The rate of researches in the field of science education in the dissertation was $21,43 \%(f=3)$. As a result, it is seen that while researchers did not go too far out of the field in the thesis studies, researchers from various fields prefer article science education in preschool period. In particular, it is observed that chemistry educators from the lower branches of Science gave importance to pre-school science education research.

\section{Findings on Content Characteristics of Research}

Table 7. Distribution of the studies according to their objectives

\begin{tabular}{|c|c|c|c|c|c|c|c|c|c|}
\hline \multirow[t]{2}{*}{ Theme } & \multirow[t]{2}{*}{ Code } & \multicolumn{2}{|c|}{$\begin{array}{l}\text { Master } \\
\text { Thesis }\end{array}$} & \multicolumn{2}{|c|}{$\begin{array}{l}\text { Doctoral } \\
\text { Thesis }\end{array}$} & \multicolumn{2}{|c|}{ Article } & \multicolumn{2}{|c|}{ Total } \\
\hline & & f & $\%$ & f & $\%$ & f & $\%$ & f & $\%$ \\
\hline \multirow{9}{*}{ Purpose } & Impact Determination & 26 & 59,10 & 14 & 70 & 11 & 14,10 & 51 & 35,92 \\
\hline & Status Determination & 10 & 22,73 & 1 & 5 & 33 & 42,31 & 44 & 30,99 \\
\hline & Opinion $\mathrm{T}$ & 5 & 11,36 & 0 & 0 & 16 & 20,51 & 21 & 14,79 \\
\hline & Relationship & 2 & 4,55 & 0 & 0 & 0 & 0 & 2 & 1,41 \\
\hline & Determination & & & & & & & & \\
\hline & Material Development & 1 & 2,27 & 1 & 5 & 0 & 0 & 2 & 1,41 \\
\hline & $\begin{array}{l}\text { Scale Development / } \\
\text { Adaptation }\end{array}$ & 0 & 0 & 4 & 20 & 4 & 5,13 & 8 & 5,63 \\
\hline & Document Review & 0 & 0 & 0 & 0 & 9 & 11,54 & 9 & 6,33 \\
\hline & Compilation & 0 & 0 & 0 & 0 & 5 & 6,41 & 5 & 3,52 \\
\hline Total & & $44^{*}$ & 100 & $20^{*}$ & 100 & $78^{*}$ & 100 & $142^{*}$ & 100 \\
\hline
\end{tabular}

* Because there are more than one purpose in some of the studies, the number of objectives in Table 7 outweighs the number of studies.

As for Table 7, it is seen that 8 codes have been created for the purpose theme. Among these, the studies on the determination of the impact measure their influence on the areas such as various methods / strategies attitude, success, learning and so on. Situation determination studies are survey studies carried out to reveal the existing sistuations such as attitudes towards science, science application level determination, and environmental awareness and to determine the status of the situation. Taking opinion is the studies conducted to get opinions from teachers, prospective teachers, parents or students on science and science related issues. Relationship determination is to measure the relationship between two variables of self-efficacy and attitude towards science. Material development is the 
studies of the preparation of alternative materials to be used during science teaching and the application of these materials. Scale development is the development of a new measurement tool or adaptation to Turkish. Document review studies include the researches collected and examined in this field. Finally, the reviews are the studies carried out in this field through literature review. In the table, it is seen that impact determination studies $(35,92 \%, f=51)$ were the most preferred codes in the total of all publication types. Then, it was followed by status determination studies $(30,99 \%, \mathrm{f}=44)$ and views $(14,79 \%, \mathrm{f}=21)$. Most of the doctoral dissertations consisted of impact determination studies $(70 \%, \mathrm{f}=14)$. The renewal of the curriculum and the alternative learning methods in the renewed programs (STEM, argumentation, research and inquiry-based learning) may have pushed researchers to determine the impact of these methods (Öztürk, 2016). Since impact determination studies are experimental studies, it is natural to prefer them in doctoral theses. Again, in the master's theses, impact determination studies $(59,10 \%, \mathrm{f}=26)$ and status determination studies $(22,73 \%, \mathrm{f}=10)$ were preferred. In the articles, more status determination studies $(42.31 \%, \mathrm{f}=$ 33) were preferred. The need to determine the current status of researchers, students, teachers, pre-service teachers, and parents may have been effective in choosing such studies. It may also be preferred as data collection is faster in such studies (Takaoğlu \& Demir, 2018). Another point that draws attention to the situation determination studies is that the majority of the studies include subjects such as self-efficacy beliefs related to the application of science activities, attitudes towards science teaching, and examination of conceptual knowledge. This may be due to the fact that preschool teachers do not have many lessons in their curriculum during their education; therefore, it is thought that they are lacking in this subject (Ültay \& Can, 2015). When we look at the scale development studies, the scale was developed in $20 \%$ ( $f=4$ ) of doctoral theses. Since the doctoral theses are generally experimental studies and based on the research of the effects of a new method / approach, it is thought that they form the scale themselves (Özkan, 2015). On the other hand, master studies do not include any scale development studies. This may be due to the fact that scale development studies contain detailed analyzes. 
Table 8. Distribution of examined studies according to research method

\begin{tabular}{|c|c|c|c|c|c|c|c|c|c|c|}
\hline \multirow[t]{2}{*}{$\begin{array}{l}\text { The } \\
\text { me }\end{array}$} & \multirow{3}{*}{$\begin{array}{l}\text { Sub Theme } \\
\text { Quantitative }\end{array}$} & \multirow[t]{2}{*}{ Code } & \multicolumn{2}{|c|}{$\begin{array}{l}\text { Master } \\
\text { Thesis }\end{array}$} & \multicolumn{2}{|c|}{$\begin{array}{c}\text { Doctoral } \\
\text { Thesis }\end{array}$} & \multicolumn{2}{|c|}{ Article } & \multicolumn{2}{|c|}{ Total } \\
\hline & & & f & $\%$ & $\mathbf{f}$ & $\%$ & f & $\%$ & f & $\%$ \\
\hline \multirow{11}{*}{ 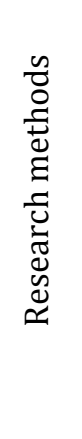 } & & Experimental & 7 & 18,42 & 8 & 57,14 & 4 & 5,19 & 19 & 14,73 \\
\hline & & Survey & 9 & 23,68 & 0 & 0 & 21 & 27,27 & 30 & 23,26 \\
\hline & & Action Research & 0 & 0 & 1 & 7,14 & 0 & 0 & 1 & 0,78 \\
\hline & & Case Study & 3 & 7,89 & 0 & 0 & 11 & 14,29 & 14 & 10,85 \\
\hline & & Exception Study & 0 & 0 & 0 & 0 & 3 & 3,90 & 3 & 2,33 \\
\hline & Qualitative & Phenomenology & 1 & 2,63 & 0 & 0 & 1 & 1,30 & 2 & 1,55 \\
\hline & & Case Study & 1 & 2,63 & 0 & 0 & 0 & 0 & 1 & 0,78 \\
\hline & & Document Analysis & 0 & 0 & 0 & 0 & 13 & 16,88 & 13 & 10,10 \\
\hline & & Ethnographic Pattern & 0 & 0 & 0 & 0 & 1 & 1,30 & 1 & 0,78 \\
\hline & & Another & 1 & 2,63 & 0 & 0 & 8 & 10,39 & 9 & 6,98 \\
\hline & Mixed & & 16 & 42,11 & 5 & 15,71 & 15 & 19,48 & 36 & 27,91 \\
\hline Total & & & 38 & 100 & 14 & 100 & 77 & 100 & 129 & 100 \\
\hline
\end{tabular}

The methods of the studies examined are given in Table 8 . It is observed that $50 \%$ $(\mathrm{f}=12)$ of researchers preferred quantitative research in their master's thesis between 2014 and 2019. It is seen that $42,11 \%(\mathrm{f}=16)$ of quantitative research had scanning patterns. It is observed that $23,68 \%(f=9)$ also gave weight to mixed studies. There are only $f=6$ studies doing qualitative research. When we look at doctoral theses, the method of most of the studies $(57,146 \%, f=8)$ was experimental pattern and $15,71 \%(f=5)$ were mixed. In contrast to master theses, in $48,06 \%$ ( $\mathrm{f}=37$ ) of the articles, qualitative research methods were preferred. The most preferred document analysis $(16.88 \%, \mathrm{f}=13)$ and case study $(14,29 \%, \mathrm{f}=11)$ were from qualitative research. The survey pattern from quantitative methods was preferred by $27,27 \%(\mathrm{f}=21)$ and the mixed method was preferred by $19,48 \%(\mathrm{f}=15)$. According to the results of all publications, the most preferred method wass quantitative method $(37,99 \%, f=49)$, survey pattern from quantitative methods $(23,26 \%, \mathrm{f}=30)$, then qualitative method $(34,15 \%$, $\mathrm{f}=44)$, then mixed method $(27,91 \%, \mathrm{f}=36)$ between 2014 and 2019. According to this result, research that prefers survey pattern has generally been done on subjects such as determining attitudes towards science education, determining skills to apply science activities and determining attitudes towards the environment (Yıld1z, 2018). The idea of researchers that researches in in science are more suitable to quantitative methods may have led to this conclusion (Bağ \& Çalık, 2018). However, the results show that a rapid increase in the number of qualitative research has been observed in recent years. It is thought that the interpretation and in-depth investigation of the results of research within the framework of the post-positivist paradigm that changes scientific acceptances is important for the reliability of scientific knowledge (Kuhn, 1962). 
Tablo 9. Distribution of the studies examined according to the participant groups

\begin{tabular}{|c|c|c|c|c|c|c|c|c|c|}
\hline \multirow[t]{2}{*}{$\begin{array}{c}\text { Them } \\
\text { e }\end{array}$} & \multirow[t]{2}{*}{ Code } & \multicolumn{2}{|c|}{$\begin{array}{l}\text { Master } \\
\text { Thesis }\end{array}$} & \multicolumn{2}{|c|}{$\begin{array}{c}\text { Doctoral } \\
\text { Thesis }\end{array}$} & \multicolumn{2}{|c|}{ Article } & \multicolumn{2}{|c|}{ Total } \\
\hline & & $\mathbf{f}$ & $\%$ & $\mathbf{f}$ & $\%$ & $\mathbf{f}$ & $\%$ & $\mathbf{f}$ & $\%$ \\
\hline \multirow{5}{*}{ 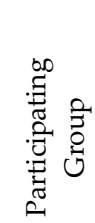 } & Student & 24 & 54,54 & 13 & 68,42 & 18 & 21,95 & 55 & 37,93 \\
\hline & Teacher & 11 & 25 & 3 & 15,79 & 32 & 39,02 & 46 & 31,72 \\
\hline & Teacher Candidate & 5 & 11,36 & 1 & 5,26 & 19 & 23,17 & 25 & 17,24 \\
\hline & Parent & 4 & 9,10 & 2 & 10,53 & 3 & 3,66 & 9 & 6,21 \\
\hline & Document & 0 & 0 & 0 & 0 & 10 & 12,20 & 10 & 6,90 \\
\hline Total & & 44 & 100 & 19 & 100 & 82 & 100 & 145 & 100 \\
\hline
\end{tabular}

Table 9 shows that $54,54 \%(\mathrm{f}=24)$ students were studied as a participant group and then teachers $(25 \%, \mathrm{f}=11)$ were studied. In doctoral theses, $68,42 \%(\mathrm{f}=13)$ were studied with students. According to the articles examined, 39,02\% ( $\mathrm{f}=32)$ teachers and $23,17 \%(\mathrm{f}=19)$ teacher candidates were identified as participants. The results here are consistent with the preferred methods. More experimental methods were preferred in doctoral theses. In other words, since the effects of the applied method/technique on the student are investigated, it is natural that the ratio of participants to the group was high in the doctoral theses of the students. Further survey studies and qualitative studies were also carried out in the articles. This type of study is thought to be preferred because it is easier to collect data from teachers and prospective teachers. Similar results are reached in the study of Ahi and Kildan (2013) which examines postgraduate theses for pre-school education. In contrast to the aforementioned results, the study of Özen Uyar and Ormanc1,(2016) on Science Education articles in preschool period concludes that more students are working with.

Table 10. Distribution of studied studies according to data collection tools

\begin{tabular}{|c|c|c|c|c|c|c|c|c|c|}
\hline Theme & \multirow[t]{2}{*}{ Code } & \multicolumn{2}{|c|}{$\begin{array}{l}\text { Master } \\
\text { Thesis }\end{array}$} & \multicolumn{2}{|c|}{$\begin{array}{c}\text { Doctoral } \\
\text { Thesis }\end{array}$} & \multicolumn{2}{|c|}{ Article } & \multicolumn{2}{|c|}{ Total } \\
\hline \multirow{9}{*}{ 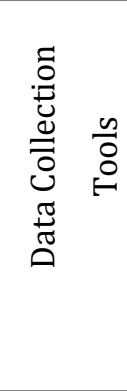 } & & f & $\%$ & $\mathbf{f}$ & $\%$ & $\mathbf{f}$ & $\%$ & $\mathbf{f}$ & $\%$ \\
\hline & Observation & 7 & 9,33 & 6 & 19,35 & 4 & 4,04 & 17 & 8,29 \\
\hline & Interview & 17 & 22,67 & 6 & 19,35 & 29 & 29,29 & 52 & 25,37 \\
\hline & Document Review & 3 & 4 & 4 & 12,90 & 18 & 18,18 & 25 & 12,20 \\
\hline & $\begin{array}{c}\text { Success /Knowledge } \\
\text { /Concept test }\end{array}$ & 8 & 10,67 & 2 & 6,45 & 7 & 7,07 & 17 & 8,29 \\
\hline & Survey/Forms & 9 & 12 & 2 & 6,45 & 13 & 13,13 & 24 & 11,71 \\
\hline & Scale & 27 & 36 & 10 & 32,26 & 26 & 26,26 & 63 & 30,73 \\
\hline & Rubrics & 4 & 5,33 & 1 & 3,23 & 0 & 0 & 5 & 2,44 \\
\hline & Metaphor & 0 & 0 & 0 & 0 & 2 & 2,02 & 2 & 0,98 \\
\hline Total & & 75 & 100 & 31 & 100 & 99 & 100 & 205 & 100 \\
\hline
\end{tabular}

Table 10 shows the distribution of data collection tools used in the studies. It is seen that the most scale and interview data collection tools were used in all publication types as well. In master theses, the data was collected most via scales $(36 \%, f=27)$, then the most preferred means of data collection was interviews $(22,67 \%, \mathrm{f}=17)$. These results are consistent with the methods preferred in master's thesis. Scales are often the preferred data collection 
tools in survey patterns. They are data collection tools used in qualitative and mixed research in interviews. It is observed that the most common survey and mixed methods were used in master's thesis. According to the doctoral theses, the most preferred data collection tool was the scales $(32,26 \%, \mathrm{f}=10)$, then observation $(19,35 \%, \mathrm{f}=6)$ and interviews $(19,35 \%, \mathrm{f}=6)$. While collecting qualitative data in doctoral theses, it is noted that observations and interviews were used together in order to increase reliability and support scientific knowledge. In the table showing the distribution of research methods, it is concluded that the most preferred method in the articles was qualitative research methods. In table10, it is seen that the most interviews $(29,29 \%, \mathrm{f}=29)$ are preferred in the articles. As with others, scales are followed $(26,26 \%, \mathrm{f}=26)$. Similar results have been obtained in recent studies (Bağ \& Çalık, 2018; Güneş, 2018). This may be due to the emphasis on mixed and qualitative studies in recent years.

Table 11. Distribution of methods / techniques used in the studies studied

\begin{tabular}{|c|c|c|c|c|c|c|c|c|c|c|}
\hline \multirow{2}{*}{\multicolumn{2}{|c|}{ Theme }} & \multirow[t]{2}{*}{ Code } & \multicolumn{2}{|c|}{$\begin{array}{l}\text { Master } \\
\text { Thesis }\end{array}$} & \multicolumn{2}{|c|}{$\begin{array}{c}\text { Doctoral } \\
\text { Thesis }\end{array}$} & \multicolumn{2}{|c|}{ Article } & \multicolumn{2}{|c|}{ Total } \\
\hline & & & f & $\%$ & $\mathbf{f}$ & $\%$ & f & $\%$ & $\mathrm{f}$ & $\%$ \\
\hline \multirow{13}{*}{\multicolumn{2}{|c|}{ 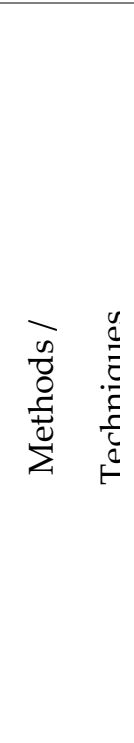 }} & STEM/ FETEMM & 4 & 10,26 & 2 & 13,33 & 1 & 1,28 & 7 & 5,30 \\
\hline & & Analogy & 1 & 2,56 & 0 & 0 & 2 & 2,56 & 3 & 2,27 \\
\hline & & Creative drama & 1 & 2,56 & 0 & 0 & 2 & 2,56 & 3 & 2,27 \\
\hline & & Argumentation & 2 & 5,13 & 2 & 13,33 & 0 & 0 & 4 & 3,03 \\
\hline & & Outdoor activities & 1 & 2,56 & 1 & 6,67 & 1 & 1,28 & 3 & 2,27 \\
\hline & & $\begin{array}{l}\text { Environmental } \\
\text { education program }\end{array}$ & 2 & 5,13 & 1 & 6,67 & 0 & 0 & 3 & 2,27 \\
\hline & & Concept cartoons & 1 & 2,56 & 0 & 0 & 0 & 0 & 1 & 0,75 \\
\hline & & Museum education & 0 & 0 & 0 & 0 & 1 & 1,28 & 1 & 0,75 \\
\hline & & Problem solving & 0 & 0 & 0 & 0 & 1 & 1,28 & 1 & 0,75 \\
\hline & & 5E method & 1 & 2,56 & 0 & 0 & 1 & 1,28 & 2 & 1,51 \\
\hline & & Picture cards & 1 & 2,56 & 0 & 0 & 1 & 1,28 & 2 & 1,51 \\
\hline & & Using model & 0 & 0 & 0 & 0 & 2 & 2,56 & 2 & 1,51 \\
\hline & & Survey & 15 & 38,46 & 0 & 0 & 59 & 75,64 & 74 & 56,06 \\
\hline Total & & & 39 & 100 & 15 & 100 & 78 & 100 & 132 & 100 \\
\hline
\end{tabular}

Table 11 shows the distribution of the methods and techniques used in the studies and their effectiveness. Studies that are not used in methods and techniques have been added to the table as a survey study. When the table is examined, it is seen that half of the master's thesis $(38,46 \%, \mathrm{f}=15)$ were survey studies. In the remaining $61,54 \%$, methods/techniques such as computer aided education, argumentation, environmental education program were used. When we examine the doctoral theses, half of the studies $(40 \%, \mathrm{f}=6)$ were given activity-based instruction. The remaining $60 \%$ included 
argumentation, brain-based training, outdoor activities, environmental education program, and experimentation. As can be seen, a method/technique was used to determine the effect in all doctoral studies. When we look at the articles, a large proportion $(75,64 \%, f=59)$ were scanned. In experimental studies, the preferred methods/techniques were more activitybased teaching $(5,13 \%, \mathrm{f}=4)$. Different methods/techniques have been used in the studies since the researches studied are largely aimed at examining the development of the students with a new method/technique. This result may be due to the fact that research prefers to work in science education subjects mostly by experimental methods. Furthermore, the increased diversity of alternative learning approaches with the updating of the curriculum and the willingness by researchers to investigate the effectiveness of these approaches may have produced such a result. On the other hand, studies aimed at due diligence were also significantly preferred (Bağ \& Çalık, 2018).

\section{Suggestions}

This study aims to determine what has been done in this field by examining the master's, doctoral theses, and articles made in the field of Science Education in preschool period in the last six years in Turkey and to show new researchers and field educators by highlighting what is needed and what is missing.

When the research is examined, it is noted that very few articles are published in SSCI-indexed journals. This may be due to the fact that the articles are mostlyscreening studies to determine the situation. More authentic studies can be emphasized to be accepted by such journals.

It is pointed out that influence determination studies are more preferred in doctoral theses. In the majority of master's theses and articles, survey studies with no method/technique are preferred. Such studies are also studies that attempt to determine attitudes towards science and the environment. The fact that such studies are being carried out continuously shows that they are repeated and prevent the emergence of original studies. The pre-school curriculum is a continuously updated program. It is thought that it will be better for literature to conduct experimental and impact determination studies with activities based on the game which have been frequently mentioned in the curriculum recently, promoting the use of close environmental facilities for educational purposes, prioritizing the development of creativity, and being a priority for children to discover and learn. 
In addition, the innovations can be adapted to the studies in our country by following the studies in the related field summer abroad.

Studies show that the attitudes of teachers and prospective teachers towards science education are good; however, they have difficulty in implementing activities and implementing new techniques. In-service training courses or BAP, TUBITAK-supported projects can be developed to address the deficiencies of teachers and teacher candidates.

The measurement and evaluation tools that are used are usually scales due to the fact that the majority of the studies are case studies. However, studies can be conducted where we combine both quantitative and qualitative research using many alternative measurement tools that enable us to investigate the subject in depth.

In the examination of studies conducted in science education in preschool period, it is seen that the authors of the studies show a variety of postgraduate education areas. This is because pre-school science education is an area that has been studied in recent years. For this reason, it contains many areas to be studied and explored. These areas should be uncovered.

This work includes only works published in Turkey. Trends can be determined by examining studies related to pre-school science education published in journals with high impact value abroad. The results determined can be compared with the results of this research to identify the deficiencies, new concepts, and variables.

Acknowledgement

The data used in this study was confirmed by the researchers that it belongs to the years before 2020.

Authorship Contribution Statement

Hatice GüLER: Conceptualization, design of the work, literature search, data analysis, data interpretation, writing - review and editing.

Erol TAŞ: Conceptualization, data collection, preliminary analyses, manuscript draft, writing, manuscript revision

\section{References}

Ahi, B. \& Kıldan, A. O. (2013). Türkiye'de okul öncesi eğitimi alanında yapılan lisansüstü tezlerin incelenmesi (2002-2011) [Investigation of graduate thesis written in pre-school education in Turkey (2002-2011)]. Mehmet Akif Ersoy University Journal of Education Faculty, 1(27), 23-46. 
$\mathrm{Au}, \mathrm{W}$. (2007). High-stakes testing and curricular control: A qualitative metasynthesis. Educational Researcher, 36(5), 258-267. doi:10.3102/0013189X07306523.

Avar, G. \& Ilıcan, S. (2018). Okul öncesi fen eğitimi alanında Türkiye'de yapılan lisansüstü tezlerin incelenmesi (2013-2017) [Investigation of pre-school graduate theses held in Turkey in the field of science education ]. Journal of Academic Social Research, 71, 1-16.

Bağ, H. \& Çalık, M. (2018). İlkokul 4. sınıf düzeyindeki fen eğitimi araştırmalarının tematik içerik analizi [Thematic content analysis of elementary school 4th grade science education research]. Elementary Education Online, 17(3), 1353-1377.

Can, Y, M. \& Aral, N., (2011). Türkiye'de okul öncesinde drama alanında yapılan lisansüstü tezlerin incelenmesi [Investigation of graduate thesis written in drama in preschool in Turkey]. Mehmet Akif Ersoy University Journal of Education Faculty, 22, 70-90.

Cevher-Kalburan, F. N. (2009). Çocuklar için çevresel tutum ölçeğgi ile yeni ekolojik paradigma ölçeği'nin geçerlik güvenirlik çalışması ve çevre eğitim programının etkisinin incelenmesi [The validity and reliability study of the environmental attitude scale for children and the new ecological paradigm scale and the impact of the environmental education program]. Unpublished Doctoral Thesis. Gazi University Institute of Educational Sciences, Ankara.

Çakmak, Ö. (2006). Okul öncesi öğretmen adaylarının fene ve fen öğretimine yönelik tutumlar ile bazı fen kavramların anlama düzeyleri arasındaki ilişkilerin incelenmesi [Examining the relationship between pre-service teachers' attitudes towards science and science teaching and their understanding of some science concepts]. Unpublished Master Thesis. Abant İzzet Baysal University, Bolu.

Çalık, M. \& Sözbilir, M. (2014). İçerik analizinin parametreleri [Parameters of content analysis]. Education and Science, 39(174), 33-38.

Ertürk-Kara, G. \& Aydın-Şengül, Ö. (2016). Türkiye'de okul öncesi dönemde fen eğitimi alanındaki çalışmaların incelenmesi [A review of studies in early childhood science education field in Turkey]. International Journal of Family Child and Education, 8, 62-63.

Gülay Ogelman, H., Önder, A., Durkan, N. \& Erol, A. (2015). Investigation of the efficiency of "We are learning about the soil with Tipitop and his friends 6" entitled soil education project. International Journal of Social Sciences and Education Research, 1 (2), 476-488.

Gülay-Ogelman, H., \& Güngör, H. (2015). Türkiye'deki okul öncesi dönem çevre eğitimi çalışmalarının incelenmesi: 2000-2014 yılları arasındaki tezlerin ve makalelerin incelenmesi [Investigating the studies on environmental education in preschool period in turkey: investigating the articles and dissertations between 2000-2014]. Mustafa Kemal University Journal of Social Sciences Institute, 12(32), 180-194.

Güneş, G. (2018). Okul öncesi fen ve doğa eğitimi araştırmalarına ilişkin bir tarama çalışması: Türkiye örneği [A survey of science and nature related to preschool education research: The case of Turkey]. Journal of Early Childhood Studies, 2(1), 33-67. 
Kaytez, N. \& Durualp, E., (2014). Türkiye'de okul öncesinde oyun ile ilgili yapılan lisansüstü tezlerin incelenmesi [Investigation of graduate thesis written about the game in preschool in Turkey]. International Journal of Turkish Educational Sciences, 2, 10-122.

Kuhn, T. S. (1962). The structure of scientific revolution. N. Kuyaş (çev.) (2008), 8. Baskı, İstanbul: Kırmızı Yayınları.

Ormancı, Ü., Çepni, S., Deveci, İ. \& Aydın, Ö. (2015). A thematic review of interactive whiteboard use in science education: Rationales, purposes, methods and general knowledge. Journal Science Education and Technology, 24, 532-548.

Özen-Uyar, R. \& Ormancı, Ü. (2016). Türkiye'de okul öncesi dönem fen eğitimi araştırmalarında güncel eğilimler: bir tematik analiz çalışması [Current trends in preschool science education research in Turkey: A thematic analysis study]. Pegem Citation Index, 559-584.

Özkan, B. (2015). 60-72 aylık çocuklar için bilimsel süreç becerileri ölçeğinin geliştirilmesi ve beyin temelli öğrenmeye dayanan fen programının bilimsel süreç becerilerine etkisi [Development of scientific process skills scale for 60-72 months old children and the effect of science program based on brain-based learning on scientific process skills]. Unpublished Doctoral Thesis. Marmara University, İstanbul.

Öztürk, M. (2016). Sorgulama temelli bilim eğitimi programının 60-72 aylık çocukların bilimsel süreç becerileriyle dil ve kavram gelişimlerine etkisi [The effect of interrogation based science education program on language and concept development of 60-72 months old children with scientific process skills]. Unpublished Doctoral Thesis. Hacettepe University, Ankara.

Saçkes, M. (2015). Kindergartners' mental models of the day and night cycle: implications for instructional practices in early childhood classrooms. Educational Sciences: Theory and Practice, 15(4), 997-1006.

Şahin, F. (2000). Okulöncesinde fen bilgisi öğretimi ve aktivite örnekleri [Science teaching and activity examples in preschool]. İstanbul: Ya-Pa Yayınları.

Takaoğlu, Z.B. \& Demir, V. (2018). Okul öncesi eğitimde uygulanan fen etkinliklerinin değerlendirilmesi [Evaluation of science activities applied in preschool education. Mediterranean Journal of Educational Research, 12(25), 76-101. doi: 10.29329/mjer.2018.153.5

Taşkın, Ö. \& Şahin, B. (2008). “Çevre” kavramı ve altı yaş okul öncesi çocuklar [The concept of "environment" and six-year-old preschool children]. Pamukkale University Journal of Education Faculty 23(1), 1-12.

Ültay, E. \& Can, M. (2015). Okul öncesi öğretmen adaylarının ısı ve sıcaklık konusundaki kavramsal bilgilerinin belirlenmesi [Determination of preschool student teachers' conceptual knowledge about "heat and temperature"]. Journal of Black Sea Social Sciences, 7(02).

Yıldız, F. A. (2018). Okul öncesi eğitimi öğretmen adaylarının ekolojik ayak izlerinin ve çevre eğitim puanlarmin incelenmesi [Investigation of pre-school education teacher candidates' ecological footprints and environmental education scores]. Unpublished Master Thesis. Ahi Evran University, Kırşehir. 
Ek 1. Bu çalışmaya dâhil edilen akademik yayınlar

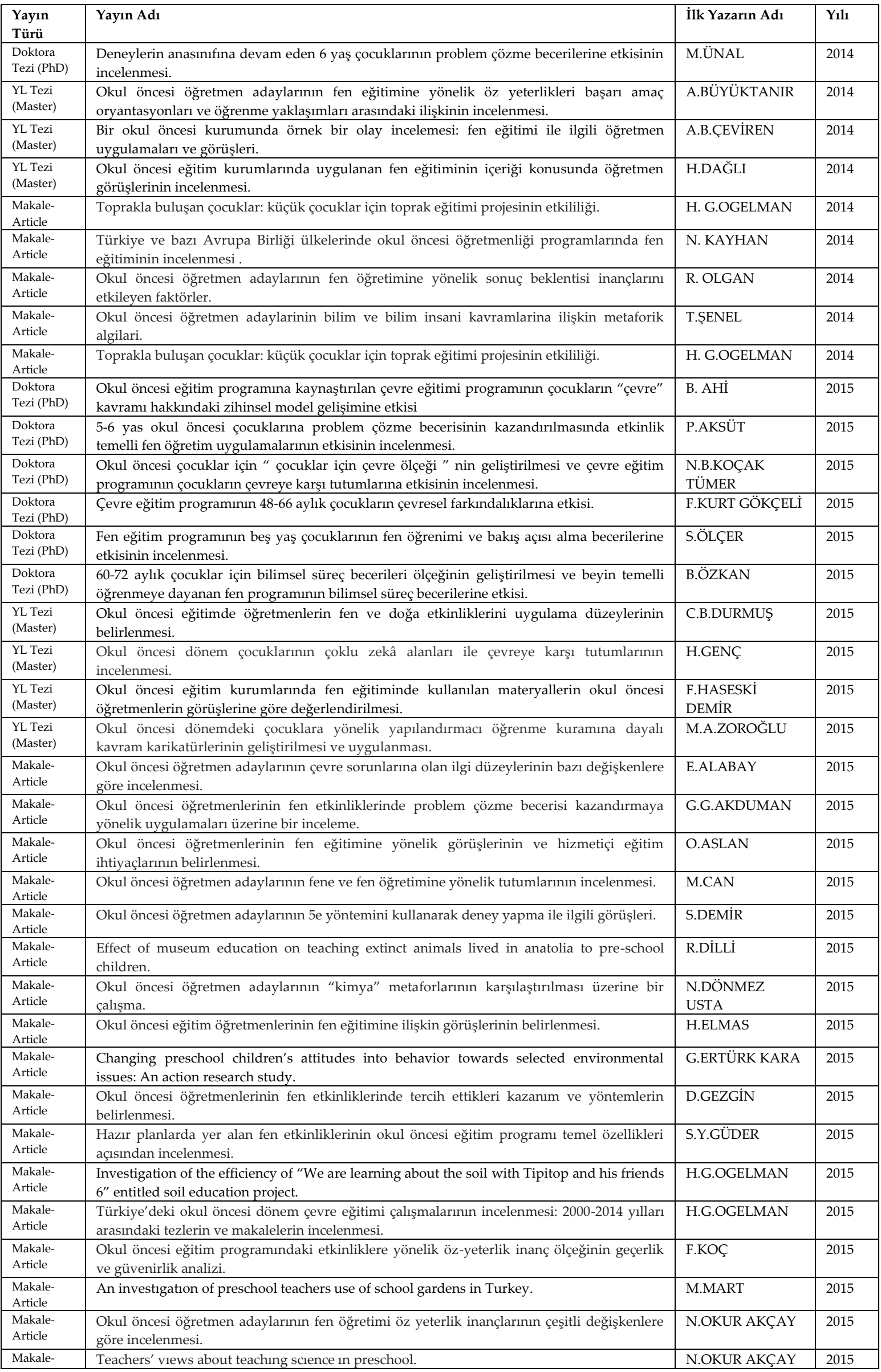


Güler $\mathcal{E}$ Taş

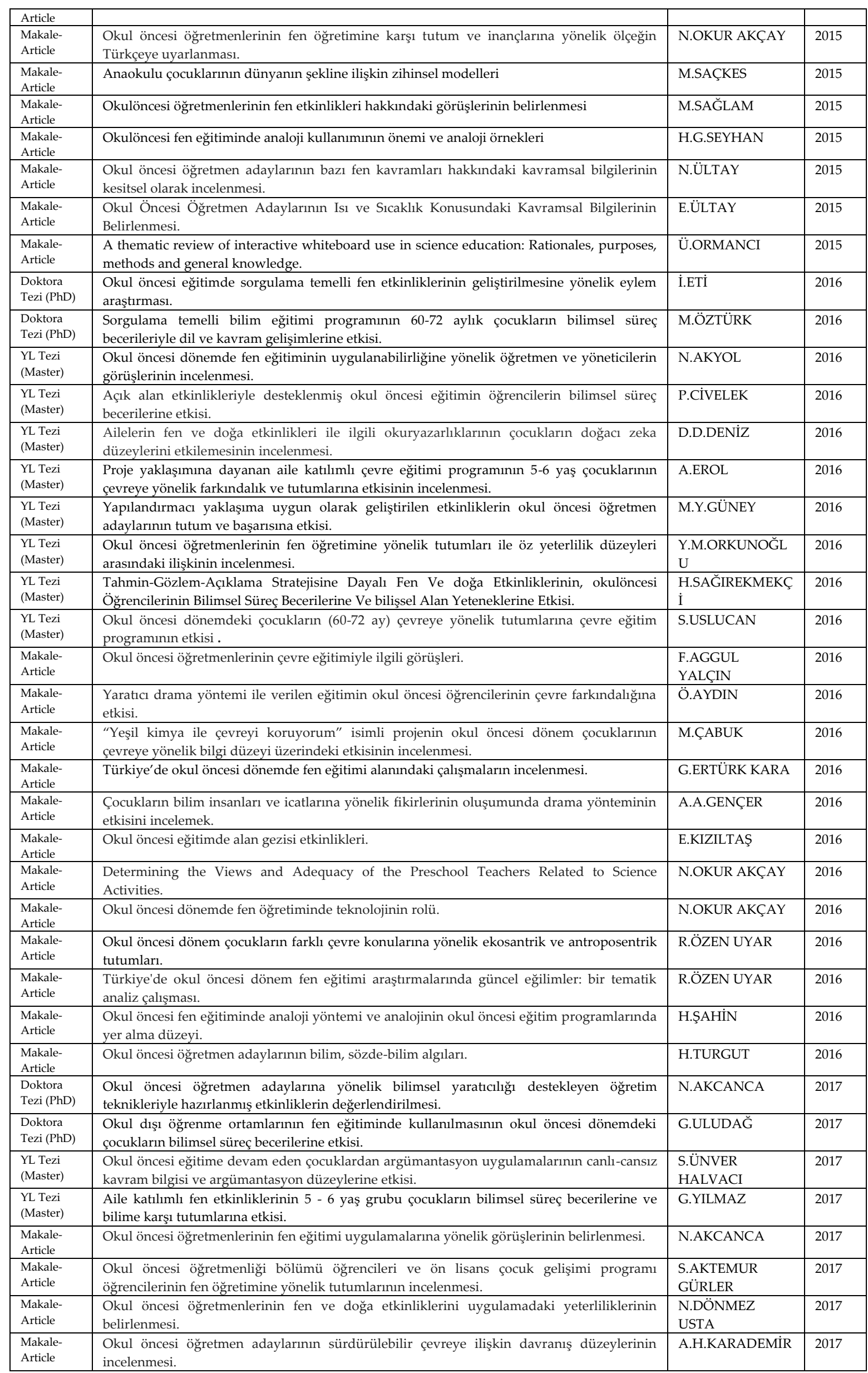


Güler \& Taş

\begin{tabular}{|c|c|c|c|}
\hline $\begin{array}{l}\text { Makale- } \\
\text { Article }\end{array}$ & Okul öncesi öğretmenlerinin çevre eğitimine yönelik görüşlerinin incelenmesi. & B.ÖZKAN & 2017 \\
\hline $\begin{array}{l}\text { Makale- } \\
\text { Article }\end{array}$ & $\begin{array}{l}\text { Okul öncesi sınıflarındaki fen merkezleri ve kullanım durumlarının incelenmesi-Kilis } \\
\text { örneği. }\end{array}$ & A.SIMSAR & 2017 \\
\hline $\begin{array}{l}\text { Makale- } \\
\text { Article }\end{array}$ & $\begin{array}{l}\text { Okul öncesi eğitim kurumlarında fen okuryazarlığına ilişkin yapılan çalışmaların } \\
\text { değerlendirilmesi. }\end{array}$ & Ö.TAHAN & 2017 \\
\hline $\begin{array}{l}\text { Makale- } \\
\text { Article }\end{array}$ & Okul öncesi öğretmen adaylarının fen eğitimine yönelik özyeterlik algıları. & P.TUĞBA ŞEKER & 2017 \\
\hline $\begin{array}{l}\text { Makale- } \\
\text { Article }\end{array}$ & Okul öncesi fen eğitiminde model kullanımı. & A.Y.TÜRKOĞLU & 2017 \\
\hline $\begin{array}{l}\text { YL Tezi } \\
\text { (Master) }\end{array}$ & $\begin{array}{l}\text { Fen eğitiminde okulöncesine yönelik yaklaşımlardan stem ve montessori yöntemlerinin } \\
\text { öğretmen görüşleri doğrultusunda karşılaştırılması. }\end{array}$ & S.AÇIKGÖZ & 2018 \\
\hline $\begin{array}{l}\text { YL Tezi } \\
\text { (Master) }\end{array}$ & $\begin{array}{l}\text { Okul öncesi dönem çocuklarında çevre kirliliği farkındalığı oluşturmada geleneksel öğretim } \\
\text { ve teknoloji destekli yöntemlerin karşılaştırılması. }\end{array}$ & F.ALTINSOY & 2018 \\
\hline $\begin{array}{l}\text { YL Tezi } \\
\text { (Master) }\end{array}$ & $\begin{array}{l}\text { Yaratıcı drama uygulamalarının okul öncesi dönemi öğrencilerinin besinler konusundaki } \\
\text { ögrenmelerine ve sosyal uyum becerileri kazanmalarına etkisi. }\end{array}$ & B.ASLAN & 2018 \\
\hline $\begin{array}{l}\text { YL Tezi } \\
\text { (Master) }\end{array}$ & $\begin{array}{l}\text { Okul öncesi öğretmenlerinin fen öğretimine yönelik tutumları ile okul öncesi eğitim } \\
\text { programında yer alan fen etkinliklerini uygulama durumları. }\end{array}$ & Z.GÜVENİR & 2018 \\
\hline $\begin{array}{l}\text { YL Tezi } \\
\text { (Master) }\end{array}$ & $\begin{array}{l}\text { Okul öncesi fen eğitiminde analojilerin ve bilgisayar destekli eğitimin akademik başarı } \\
\text { açısından değerlendirilmesi. }\end{array}$ & $\begin{array}{l}\text { R.KARABULUTL } \\
\text { U }\end{array}$ & 2018 \\
\hline $\begin{array}{l}\text { YL Tezi } \\
\text { (Master) }\end{array}$ & $\begin{array}{l}\text { Anne babaların ve okul öncesi grubu çocuklarının çevre bilincine sahip olma durumlarının } \\
\text { değerlendirilmesi. }\end{array}$ & F.KARACA & 2018 \\
\hline $\begin{array}{l}\text { YL Tezi } \\
\text { (Master) }\end{array}$ & $\begin{array}{l}\text { Okul öncesi eğitimi öğretmen adaylarının ekolojik ayak izlerinin ve çevre eğitim puanlarının } \\
\text { incelenmesi. }\end{array}$ & A.F.YILDIZ & 2018 \\
\hline $\begin{array}{l}\text { Makale- } \\
\text { Article }\end{array}$ & $\begin{array}{l}\text { Mental images and method-technique approaches of teacher candidates of preschool } \\
\text { teaching towards science education. }\end{array}$ & $\begin{array}{l}\text { M.ALKIŞ } \\
\text { KÜÇÜKAYDIN }\end{array}$ & 2018 \\
\hline $\begin{array}{l}\text { Makale- } \\
\text { Article }\end{array}$ & $\begin{array}{l}\text { Okul öncesi fen eğitimi alanında Türkiye'de yapılan lisansüstü tezlerin incelenmesi (2013- } \\
\text { 2017). }\end{array}$ & G.AVAR & 2018 \\
\hline $\begin{array}{l}\text { Makale- } \\
\text { Article }\end{array}$ & Erken çocukluk döneminde fen eğitimine ilişkin okulöncesi öğretmenlerinin görüşleri. & A.BABAROĞLU & 2018 \\
\hline $\begin{array}{l}\text { Makale- } \\
\text { Article }\end{array}$ & $\begin{array}{l}\text { Preschool teachers' views on science education, the methods they use, science activities, and } \\
\text { the problems they face. }\end{array}$ & Y.DOĞAN & 2018 \\
\hline $\begin{array}{l}\text { Makale- } \\
\text { Article }\end{array}$ & Okul öncesi fen ve doğa eğitimi araştırmalarına ilişkin bir tarama çalışması: Türkiye örneği. & G.GÜNEŞ & 2018 \\
\hline $\begin{array}{l}\text { Makale- } \\
\text { Article }\end{array}$ & Çocuklar için ekolojik ayak izi farkındalık ölçeği'nin (EKAY-Ö) geliştirilmesi. & H.GÜNGÖR & 2018 \\
\hline $\begin{array}{l}\text { Makale- } \\
\text { Article }\end{array}$ & $\begin{array}{l}\text { Ebeveynlerin, fene ve okul öncesi dönemde fen etkinliklerine yönelik görüşlerini belirleme } \\
\text { ölçeği'nin geliştirilmesi. }\end{array}$ & Ç.ŞAHİN & 2018 \\
\hline $\begin{array}{l}\text { Makale- } \\
\text { Article }\end{array}$ & Okul öncesi eğitimde uygulanan fen etkinliklerinin değerlendirilmesi. & Z.B.TAKAOĞLU & 2018 \\
\hline $\begin{array}{l}\text { Makale- } \\
\text { Article }\end{array}$ & Preschool teachers in the context of teaching astronomy. & C.TÜRK & 2018 \\
\hline $\begin{array}{l}\text { Makale- } \\
\text { Article }\end{array}$ & Okul öncesi öğretmenlerinin fen konularındaki uygulamalarının incelenmesi. & N.ÜLTAY & 2018 \\
\hline $\begin{array}{l}\text { Makale- } \\
\text { Article } \\
\end{array}$ & Okul öncesi öğretmenlerinin fen etkinliklerine yer verme durumlarının değerlendirilmesi. & S.YILDIZ & 2018 \\
\hline $\begin{array}{l}\text { Makale- } \\
\text { Article }\end{array}$ & $\begin{array}{l}\text { Okul öncesi eğitiminde fen eğitimi temelinde gerçekleştirilen STEM uygulamalarının } \\
\text { öğrenci, öğretmen ve veli açısından değerlendirilmesi. }\end{array}$ & D.AKGÜNDÜZ & 2018 \\
\hline $\begin{array}{l}\text { Doktora } \\
\text { Tezi } \\
(\mathrm{PhD})\end{array}$ & $\begin{array}{l}\text { Okul öncesi eğitimde stem temelli aile katılımlı bir mühendislik tasarım müfredatının } \\
\text { geliştirilmesi. }\end{array}$ & A.ATA AKTÜRK & 2019 \\
\hline $\begin{array}{l}\text { Doktora } \\
\text { Tezi }(\mathrm{PhD})\end{array}$ & $\begin{array}{l}\text { Bir okul öncesi eğitim kurumunda ekolojik ayak izi uygulamaları ile sürdürülebilir yaşam } \\
\text { fırsatlarının geliştirilmesi. }\end{array}$ & H.GÜNGÖR & 2019 \\
\hline $\begin{array}{l}\text { Doktora } \\
\text { Tezi (PhD) }\end{array}$ & $\begin{array}{l}\text { Okul öncesi ve temel fen eğitiminde robotik destekli ve basit malzemelerle yapılan stem } \\
\text { uygulamalarının karşılaştırılması. }\end{array}$ & A.KOÇ & 2019 \\
\hline $\begin{array}{l}\text { YL Tezi } \\
\text { (Master) }\end{array}$ & $\begin{array}{l}\text { Bilim içerikli oyunlar yoluyla fen eğitiminin okul öncesi dönemi çocukları üzerindeki } \\
\text { etkileri. }\end{array}$ & G.AKBABAOĞLU & 2019 \\
\hline $\begin{array}{l}\text { YL Tezi } \\
\text { (Master) }\end{array}$ & $\begin{array}{l}\text { STEM etkinliklerinin anaokuluna devam eden } 6 \text { yaş çocukların problem çözme becerilerine } \\
\text { etkisi. }\end{array}$ & B.AKÇAY & 2019 \\
\hline $\begin{array}{l}\text { YL Tezi } \\
\text { (Master) }\end{array}$ & $\begin{array}{l}\begin{array}{l}\text { Farklı okul öncesi eğitim modellerinin } 54-66 \text { aylık çocukların çevre tutum ve } \\
\text { farkındalıklarına etkisi. }\end{array} \\
\end{array}$ & C.G.ALPARSLAN & 2019 \\
\hline $\begin{array}{l}\text { YL Tezi } \\
\text { (Master) }\end{array}$ & $\begin{array}{l}\text { Okul öncesi öğretmen adaylarının fen ve doğa etkinliklerinde pop-up book tekniğinin } \\
\text { kullanımına ilişkin tutumları ve bu tutumları etkileyen faktörler }\end{array}$ & A.AYDIN & 2019 \\
\hline $\begin{array}{l}\text { YL Tezi } \\
\text { (Master) }\end{array}$ & Okul öncesi dönemdeki fen etkinlikleri uygulamalarının çocuk resimleri ile incelenmesi. & S.BİLGİŞ & 2019 \\
\hline $\begin{array}{l}\text { YL Tezi } \\
\text { (Master) }\end{array}$ & Doğa eğitiminin okul öncesi çocukların sosyal becerilerine etkisinin incelenmesi. & K.ÇİFTÇİ & 2019 \\
\hline $\begin{array}{l}\text { YL Tezi } \\
\text { (Master) }\end{array}$ & $\begin{array}{l}\text { Okul öncesi eğitimde drama temelli erken STEM programının bilimsel süreç ve yaratıcı } \\
\text { düşünme becerilerine etkisi. }\end{array}$ & $\begin{array}{l}\text { S.ÇİLENGİR } \\
\text { GÜLTEKİN }\end{array}$ & 2019 \\
\hline $\begin{array}{l}\text { YL Tezi } \\
\text { (Master) }\end{array}$ & Fen etkinliklerinin okul öncesi dönem çocuklarında çevre bilinci kazandırılmasına etkisi. & D.GEZGIN & 2019 \\
\hline $\begin{array}{l}\text { YL Tezi } \\
\text { (Master) }\end{array}$ & Okul öncesi eğitiminde STEM etkinliklerinin yaratıcılığa etkisi. & S.GÜLDEMİR & 2019 \\
\hline $\begin{array}{l}\text { YL Tezi } \\
\text { (Master) }\end{array}$ & $\begin{array}{l}\text { Okul öncesi öğretmenlerin aldıkları STEM eğitimine ilişkin düşünceleri ve sınıf içi } \\
\text { uygulamalarının incelenmesi. }\end{array}$ & $\begin{array}{l}\text { Ş.KARAMETE } \\
\text { GÖZCÜ }\end{array}$ & 2019 \\
\hline $\begin{array}{l}\text { YL Tezi } \\
\text { (Master) }\end{array}$ & $\begin{array}{l}\text { Beş yaş çocuklarına uygulanan iklim değişikliği programının çocukların iklim değişikliği } \\
\text { kavramı hakkındaki görüşlerine etkisi. }\end{array}$ & $\begin{array}{l}\text { C.MAVIŞ } \\
\text { DEMIRCIOĞLU }\end{array}$ & 2019 \\
\hline
\end{tabular}


Güler \& Taş

\begin{tabular}{|c|c|c|c|}
\hline $\begin{array}{l}\text { YL Tezi } \\
\text { (Master) }\end{array}$ & Okul öncesi dönemdeki çocukların doğa algılarının resimler yoluyla incelenmesi & S.MOL & 2019 \\
\hline $\begin{array}{l}\text { YL Tezi } \\
\text { (Master) }\end{array}$ & $\begin{array}{l}\text { STEM odaklı olarak yeniden tasarlanan okulöncesi öğretmenliği bölümü fen ve matematik } \\
\text { eğitimi dersinin uygulanma süreci: bir durum çalışması. }\end{array}$ & A.SAĞBAŞ & 2019 \\
\hline $\begin{array}{l}\text { YL Tezi } \\
\text { (Master) }\end{array}$ & $\begin{array}{l}\text { Reggio Emilia yaklaşımı temelli fen ve doğa etkinliklerinin uygulanması: bir eylem } \\
\text { araştırması. }\end{array}$ & A.ŞAHİN & 2019 \\
\hline $\begin{array}{l}\text { Makale- } \\
\text { Article }\end{array}$ & Okul öncesinde fen öğretimi, bilim ve teknoloji. & E.AKŞİN YAVUZ & 2019 \\
\hline $\begin{array}{l}\text { Makale- } \\
\text { Article }\end{array}$ & MEB okul öncesi fen etkinliklerinin bilimsel süreç becerileri açısından incelenmesi. & D.BİNGÖL & 2019 \\
\hline $\begin{array}{l}\text { Makale- } \\
\text { Article }\end{array}$ & $\begin{array}{l}\text { Montessori yaklaşımı temelli STEM etkinliklerinin okul öncesi öğretmen adaylarının } \\
\text { yaratıcılık becerilerine etkisi. }\end{array}$ & Z.ÇAKIR & 2019 \\
\hline $\begin{array}{l}\text { Makale- } \\
\text { Article }\end{array}$ & Erken çocukluk döneminde çevre eğitimi içerikli resimli çocuk kitaplarının incelenmesi. & T.GÜZELYURT & 2019 \\
\hline $\begin{array}{l}\text { Makale- } \\
\text { Article }\end{array}$ & $\begin{array}{l}\text { Comparing predictors of teachers' education for sustainable development practices among } \\
\text { eco and non-eco preschools. }\end{array}$ & $\begin{array}{l}\text { D.KAHRIMAN } \\
\text { PAMUK }\end{array}$ & 2019 \\
\hline $\begin{array}{l}\text { Makale- } \\
\text { Article }\end{array}$ & Okul öncesi öğretmen adaylarının FETEMM farkındalıklarının değerlendirilmesi. & $\begin{array}{l}\text { Z.KOYUNLU } \\
\text { ÜNLÜ }\end{array}$ & 2019 \\
\hline $\begin{array}{l}\text { Makale- } \\
\text { Article }\end{array}$ & Okul öncesi ağaç bilim okulu etkinlikleri. & P.KÖSEOĞLU & 2019 \\
\hline $\begin{array}{l}\text { Makale- } \\
\text { Article }\end{array}$ & $\begin{array}{l}\text { Okul öncesi dönemde çocukların astronomi konusunda temel kavramlarla ilgili bilgilerinin } \\
\text { incelenmesi }\end{array}$ & Ü.İ.ONBAŞILI & 2019 \\
\hline $\begin{array}{l}\text { Makale- } \\
\text { Article }\end{array}$ & $\begin{array}{l}\text { Okul öncesi öğretmenlerinin okullarındaki fen merkezine ve fen eğitimine yönelik bakış } \\
\text { açıları. }\end{array}$ & A.T.ORHAN & 2019 \\
\hline $\begin{array}{l}\text { Makale- } \\
\text { Article }\end{array}$ & $\begin{array}{l}\text { Okul öncesi öğretmenlerinin yaratıcılık düzeyleri ile 60-72 aylık çocukların fen öğreniminin } \\
\text { karşılaştırılması. }\end{array}$ & S.ÖLÇER & 2019 \\
\hline $\begin{array}{l}\text { Makale- } \\
\text { Article }\end{array}$ & Okul öncesi dönemde fen eğitimi ve önemi. & T.K.ÖNAL & 2019 \\
\hline $\begin{array}{l}\text { Makale- } \\
\text { Article }\end{array}$ & Okul öncesi öğretmenlerinin fen eğitimi süreçleri üzerine görüşlerinin incelenmesi. & A.SİMSAR & 2019 \\
\hline $\begin{array}{l}\text { Makale- } \\
\text { Article }\end{array}$ & $\begin{array}{l}\text { En iyi öğretmenim doğa: okul öncesinde doğa temelli eğitim uygulamaları projesi } \\
\text { kapsamında hazırlanan öğretmen etkinlikleri. }\end{array}$ & Z.TEMİZ & 2019 \\
\hline $\begin{array}{l}\text { Makale- } \\
\text { Article }\end{array}$ & $\begin{array}{l}\text { Determination of preschool teachers' self-efficacy beliefs for science activities in preschool } \\
\text { curriculum. }\end{array}$ & M.TUNCER & 2019 \\
\hline $\begin{array}{l}\text { Makale- } \\
\text { Article }\end{array}$ & $\begin{array}{l}\text { Okul öncesi dönemdeki çocukların bilim insanı olarak yapmak istediklerine ilişkin } \\
\text { görüşlerinin resimler yoluyla incelenmesi. }\end{array}$ & E.YAZICI & 2019 \\
\hline
\end{tabular}

\section{Copyright $\odot$ JCER}

JCER's Publication Ethics and Publication Malpractice Statement are based, in large part, on the guidelines and standards developed by the Committee on Publication Ethics (COPE). This article is available under Creative Commons CC-BY 4.0 license (https://creativecommons.org/licenses/by/4.0/) 